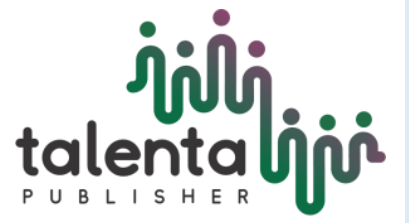

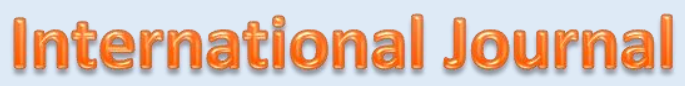
of Ecophysiology

\title{
Description of Kidney Histology of Mus musculus After Giving Nano Hebal Rhodomyrtus tomentosa (Haramounting)
}

\author{
Putri Cahaya Situmorang ${ }^{1}$, Syafruddin Ilyas ${ }^{1 *}$ \\ ${ }^{1}$ Department of Biology, Faculty of Mathematics and Natural Sciences, Universitas Sumatera Utara, \\ Jalan Dr.Mansyur Medan, Indonesia, 20155
}

\begin{abstract}
The objective of this study was to determine the description of kidney histology of Mus musculus after giving Nano Herbal Rhodomyrtus tomentosa (Haramonting). R.tomentosa (Haramonting) is made on a nanoscale using High Energy Milling (HEM). This research use the Completely Randomized Design (CRD), which consists of six groups of CMC $0.5 \%$ and Nano- R.tomentosa (Haramonting) at dosage of (100; 141,42; 200; $282,82 ; 400) \mathrm{mg} / 20 \mathrm{~g}$ body weight. The kidneys were made into preparations by using the paraffin method and Hematoxylin Erlich-Eosin staining (HE). The results of histological kidneys showed that there is a significant difference $(\mathrm{P}<0,05)$ between control group and treatment groups with damaged cells and increased proximal tubular narrowing in kidneys, but there was not significantly different in weight of kidneys $(P>0,05)$.
\end{abstract}

Keywords: Nano Herbal, Rhodomyrtus tomentosa, Herbal medicines, Histology, Kidneys

Received 1 November 2018 | Revised 20 December 2018 | Accepted 20 January 2019

\section{Introduction}

Herbal medicines have less adverse effects as compared with modern medicines. The delivery of plant/herbal therapeutic molecules as drugs is problematic due to poor solubility, poor permeability, low bioavailability, instability in biological milieu and extensive first pass metabolism (Rinku et al, 2018). The modern phyto-pharmaceutical research can solve the scientific needs of herbal medicines in developing novel drug delivery systems, such as nanoparticles, micro emulsion, matrix system, solid dispersion, liposomes and solid lipid nanoparticles. The complexity of active constituents makes the development of novel drug delivery system for herbal formulations very challenging (Kumar and Rai, 2012; Sharma et al, 2011).

\footnotetext{
*Corresponding author at: J1. Dr.Mansyur Medan, Indonesia, 20155

E-mail address: syafruddin6@usu.ac.id
} 
Leaves of Rhodomyrtus tomentosa (Haramonting) is one of 1000 plants in Indonesia that can be used as traditional medicine. Many people use leaves of haramonting to treat colic, diarrhea, dysentery, abscesses, bleeding, abdominal pain, neutralizing toxins and wounds (WHO,1989; Kissinger et al, 2013). The Indian earliest literature, reports more than 800 herbal plant species with anti-diabetic properties (Aparajeya et al, 2015). Herbs are also known to provide alternative therapy in the inhibition of the diabetic complications, including cholesterol lowering action. Some of these herbs also have been confirmed to help in the redevelopment of $\beta$-cells and in overwhelming insulin resistance (Ahmad et all, 2006). Haramonting leaf water fraction affects the weight of male mice,reduce urine volume, and reduce blood glucose levels diabetic mice induced by alloxan (Sinata and Helmi, 2016). The results showed that haramonting leaves contained phenol group compounds, flavonoids, saponins, tannins, steroids and triterpenoids (Dwicahmi, 2015). Antioxidants in haramonting leaves are able to bind free radicals so as to reduce oxidative stress. Reduced oxidative stress can reduce insulin resistance, and prevent the development of dysfunction, and pancreatic $\beta$ cell damage (Song et al, 2005). Research results show that flavonoids have activity antidiabetic through its function as an antioxidant (Lukacinova, 2008). Aqueous extract of haramonting leaf at a dose of $100 \mathrm{mg} / \mathrm{kg}$ is the dose that gives the best effect in lowering blood sugar levels in mice (Hasibuan et al, 2015). Research using extract of R.tomentosa has been done a lot. However, using Nano Herbal of R.tomentosa has not been done. So in this study, we examined to kidney cells after giving Nano-R.tomentosa. So, Nano-R.tomentosa as a new alternative in the treatment of certain diseases.

\section{Materials and Methods}

The material used are Haramonting leaves (R.tomentosa) obtained from plantation residents in Tapanuli North Sumatera and Mus musculus, This research use the Completely Randomized Design (CRD) using 30 male mice with an average weight of 20-25g age 12-18 weeks. Male mice are kept in Animal Cages Biological Laboratory, Faculty Mathematics and Natural Science, Universitas Sumatera Utara. Experimental animal handling is done ethically (Ethical Clearance).

Haramonting is made into a nanoscale using High Energy Milling (HEM), then inserted into the jar container, Inserting balls with larger diameter size then continued by inserting small balls and the last sample and HEM is turned on for 2 hours.

The treatment consisted of 6 groups consisting of 5 male mice ie Control (CMC 0.5\%) and Nano-R.tomentosa (Haramonting) at dosage of (100; 141,42; 200; 282,82;400)mg/20g body weight in 14 days, then killed by the method of disclasio cervicalis to take the kidney. Preparation of histologist by paraffin method and Hematoxylin Erlich-Eosin staining (HE) to observe the damage to kidney cells due to the administration of Nano-R.tomentosa and then the data processed with SPSS 22 program with Kruskal Wallis test. 


\section{Result and Discussion}

Administration of Nano-R.tomentosa (Haramonting) was not significantly different in weight of kidney $(\mathrm{P}>0,05)$. Based on graph (figure 1) There is almost no difference in kidney in each treatment. Weight of kidney was highest in the control group and T2, T1 treatment with T4 was almost the same weight, as well as at T3 and T5 doses. So that it can be seen that the administration of Nano-R.tomentosa (Haramonting) in the weight of the kidneys does not show any significant differences in each dose (figure 1).

Statistical data analysis test results to kidney are significant differences between the control groups with each treatment $(\mathrm{P}<0.05)$ with Kruskal Wallis test in each dose level (figure 2). In Mann Whitney test, $\mathrm{P}>0.05$ in Control with $\mathrm{T} 1, \mathrm{~T} 1$ with $\mathrm{T} 2, \mathrm{~T} 2$ with $\mathrm{T} 3, \mathrm{~T} 2$ with $\mathrm{T} 4, \mathrm{~T} 3$ with T4 with T5, and T4 with T5. Based on graph (figure 2), It has also almost the same value even though the overall treatment differs significantly. So, There were not difference between certain treatments. Administration of Nano-R.tomentosa (Haramonting) with multilevel doses can cause necrosis with varying degrees of damage (Pyknosis, Karyorrhexis, Karyolysis).

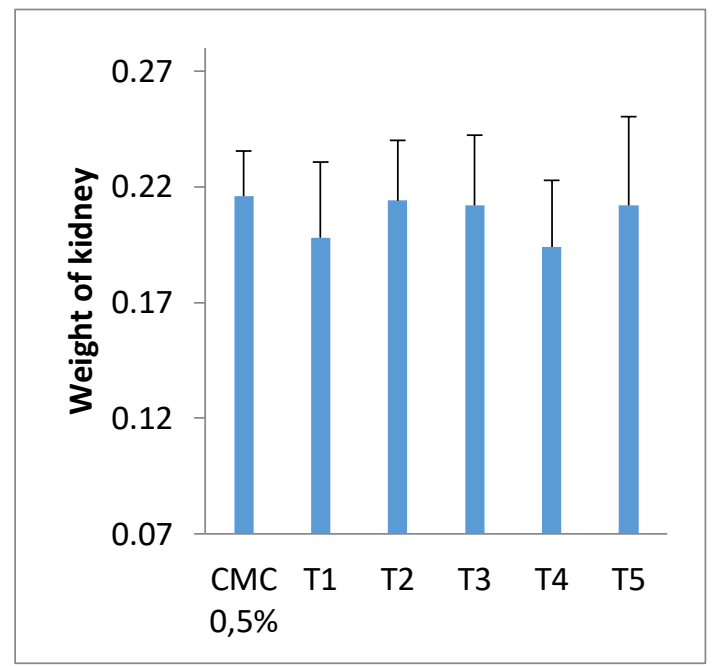

Figure 1. Weight of kidney $(\bar{X} \pm$ SD)

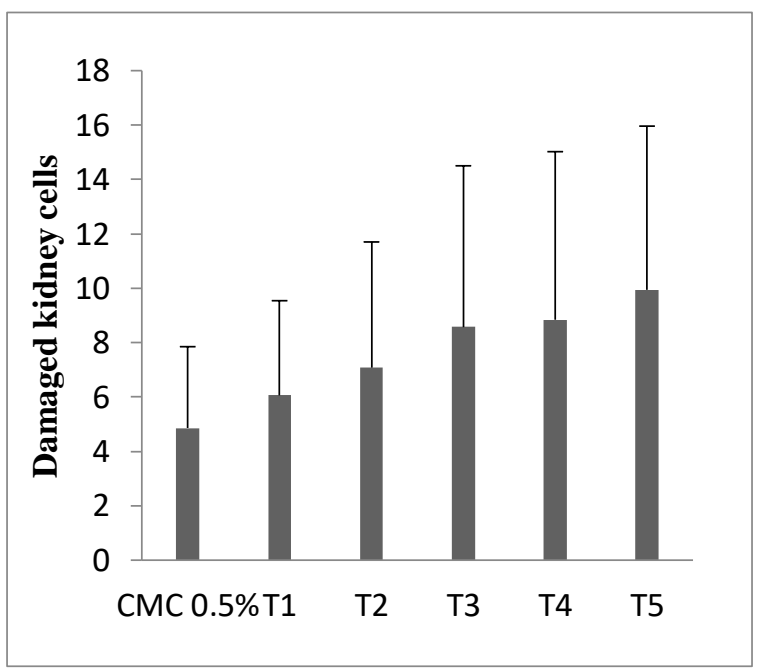

Figure 2. Comparison of damaged kidney cells( $\bar{X} \pm \mathbf{S D})$.

Based on observations that have been made it is seen that Pyknosis, Karyorrhexis and Karyolysis is highest at T5 and the lowest occurs in the control group (CMC 0.5\%) (figure 3). Pyknosis occurs with shrinkage of the core and dark color, Karyorrhexis with a broken core forming fragments and necrosis is characterized by reduced color absorption by the nucleus, and the release of tubular cells into the lumen resulting in renal cell damage in each treatment. From the control group ( $0.5 \% \mathrm{CMC})$, T1 to T5 occurred renal cell necrosis with Pyknosis, Karyorrhexis and Karyolysis which increased each dose level (figure 3). So, the higher the dose of Nano-R.tomentosa, the greater the necrosis in the kidney cells (figure 2). 


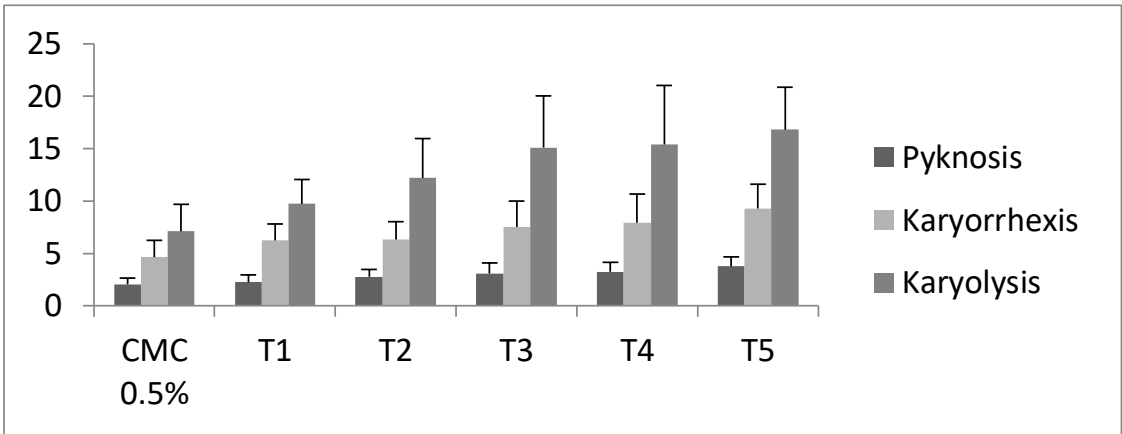

Figure 3. Average of Pyknosis, Karyorrhexis, Karyolysis after giving Nano-R.tomentosa

$$
(\bar{X} \pm \text { SD) }
$$

In addition to kidney necrosis with varying degrees of damage, Administration of Nano-R.tomentosa affects the shape of the renal tubules. Based on graph, the control group had the lowest tubular narrowing compared to the treatment group (Figure 4). Tubular narrowing increases every treatment even at the highest dose reaching 52\% in T5. Cell damage to the kidneys, due to excessive doses of Nano-R.tomentosa like necrosis characterized by narrowing of the lumen of the tubular cell, and unclear boundaries between cells. The control treatment also occurred $19 \%$ narrowing of the tubules. Increased narrowing of the tubules at the dose began to increase in the treatment of T2 $(41 \%), \mathrm{T} 3(45 \%)$ and $\mathrm{T} 4(48 \%)$ while the $\mathrm{T} 1$ is still $26 \%$.

Based on histology, it can be seen that in the control group (CMC 0.5\%) the proximal tubule is still open, and the shape between cells is still clear even though there are several narrowed tubules. After administration of Nano-R. tomentosa the narrowing of the tubules increases, and is clearly seen in kidney histology. The narrowing of the renal tubules is more clearly seen in T3, T4 to T5 and it's hard to find the boundary between tubules. In T5 kidney cell damage (necrosis) is obvious, as are narrowed tubules (figure 5).

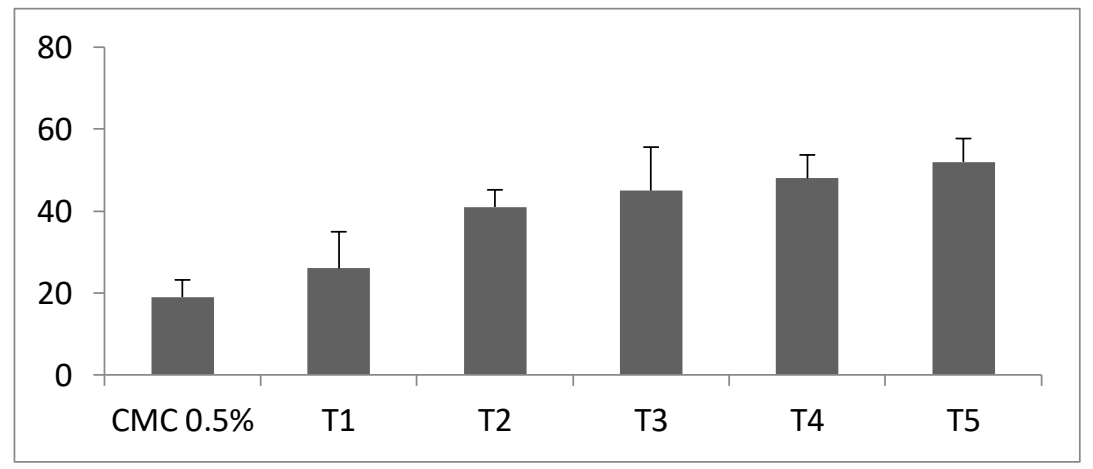

Figure 4. Percentage of Narrowed Proximal Tubules ( $\bar{X} \pm$ SD) 

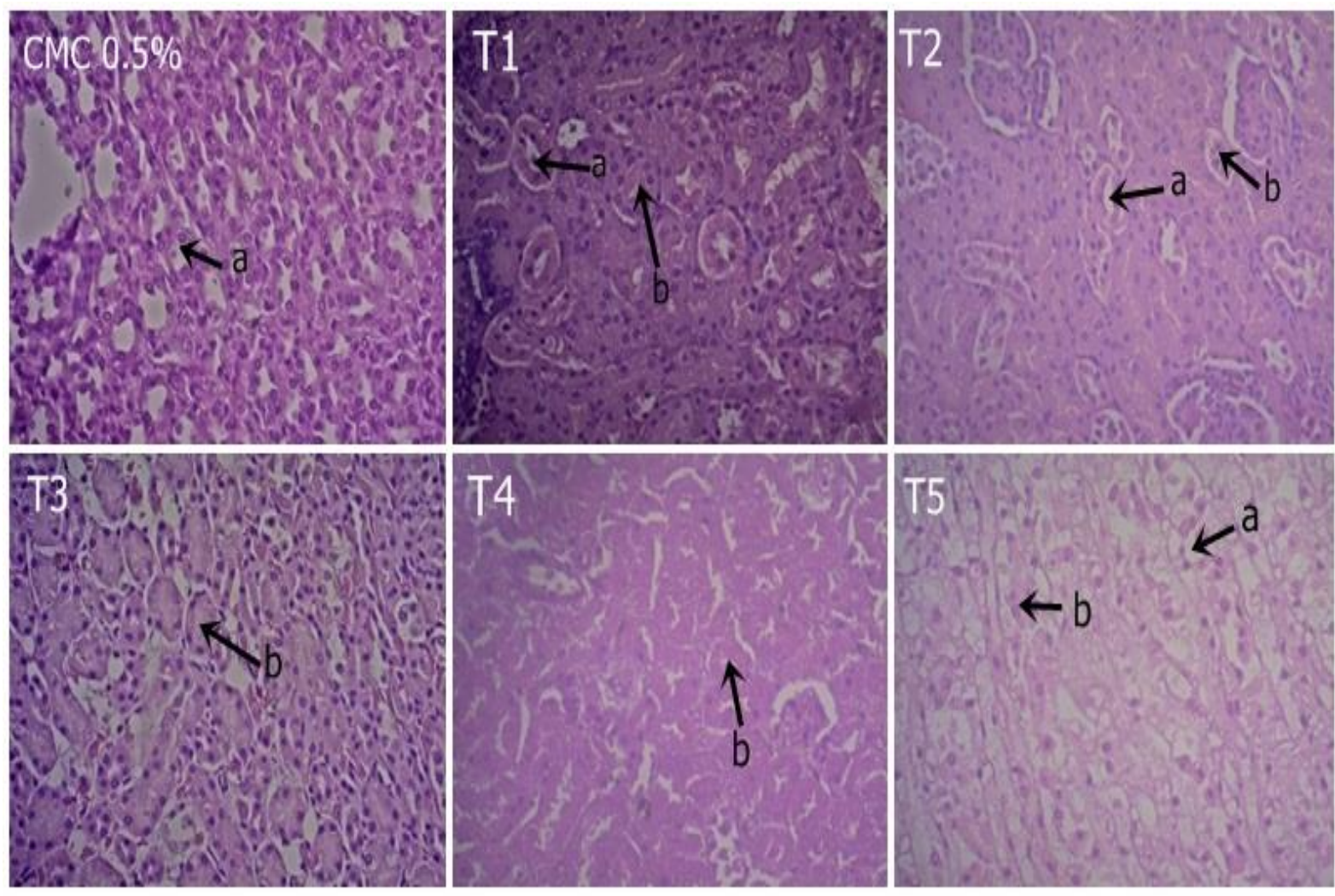

Figure 5. Histology of kidney, a. The Proximal Tubule that is open, b. The Proximal Tubule that is narrowed $(400 x)$.

Changes in the histological structure of the kidneys are certainly influenced by the amount of compounds in the body like compounds in Nano.R.tomentosa, But it does not affect the weight of the kidney in mice. Even in the highest dose treatment. It depends on the body's response and the metabolism of the mice.The results showed that various doses of Nano-R.tomentosa given to mice, causing changes significant on the structure of kidney histology. Haramonting has secondary metabolites such as phenols, flavonoids, saponins, tannins, steroids and triterpenoids. Phenol, flavonoids, tannins, steroids and triterpenoids are known to have antioxidant effects (Sestili et al, 1998; Tommy, 2013). But Saponins are secondary metabolites that are suspected of causing damage to the kidneys. Saponins can cause hemolysis by influencing lipid bilayers in the protein membranes of red blood cells thus causing pore formation in the red blood cell membrane (Baumann et al, 2005; Gauthier et al, 2009). Phenol compounds when given in high enough doses can act as cytotoxic compounds (Scapagnini et al, 2004). The metabolic results of some toxic compounds released by the kidneys can cause kidney dysfunction (Moneim et al, 2017). Toxicity depends on the dose; a decrease in body fluid volume can predispose to toxicity (Jannete et al, 2015). Haramonting on the nanoscale can cause increased cell necrosis (Pyknosis, Karyorrhexis and Karyolysis) in each dose level. In 
necrotic cells there is a change in the nucleus, which is the loss of chromatin, the nucleus becomes wrinkled, no longer vascular, the nucleus appears denser, the color is dark black (Pyknosis), the nucleus is divided into fragments, torn (Karyorrhexis), the nucleus no longer takes on many colors because it is pale not real (Karyolysis). The control group in this study also showed degeneration and necrosis in renal tubular cells (figure 2 and 3). but in a smaller amount when compared to other treatment groups. This can be caused by a cell aging process or histological artifacts due to improper sample tissue handling (Kumar et al, 2015; Rastogi et al, 2013). The occurrence of necrosis in the kidney after the administration of excessive compounds can cause adverse effects on renal blood flow. The high blood flow to the kidneys, causing a variety of drugs, and chemicals in the systemic circulation, are sent to the kidneys in large numbers. These toxic substances will accumulate in the kidneys, and cause damage to the kidneys (Robbins and Kumar, 2007).

In addition to necrosis, tubular narrowing occurs in the kidneys, It occurs due to degeneration of albuminosa or cloudy swelling (swollen cloudy), which is the mildest form of degeneration and reversible. This is what may cause the proximal tubule lumen to narrow until it closes. In addition to saponins, the presence of hemoglobin, heme and iron is free in the tubules, causing cell damage and cell death (Gutierrez et al, 2012). Toxic hemoglobin is direct to tubular cells, tubular damage can also occur due to hemodynamic disturbances so there is a decrease in nitric oxide which causes a decrease in blood flow in the kidneys (Brezis et al, 1991). Free hemoglobin which is filtered in the glomerulus, will cause tubular epithelial damage. Free hemoglobin can also induce intratubular cast formation, in addition free hemoglobin is a strong inhibitor of NO which triggers intrarenal vasoconstriction and ischemia (Fauci et al, 2008; O'Callaghan and Brenner, 2000).

\section{Conclussion}

Administrationof Nano-R.tomentosa is significantly different from each treatment $(\mathrm{P}<0.05)$ in kidneys, but there was not significantly different in weight of kidney $(P>0,05)$ and Nano herbal of Haramonting with excessive doses causes increased proximal tubular narrowing.

\section{Aknowledgement}

We are grateful to Directorate of research and community service, Directorate general of research and development, Ministry of research, Technology, and Higher Education in accordance with research and community service funding agreement for budgeting year 2018 (Fund of the research postgraduate team I) to funding our research. 


\section{References}

[1] Ahmad, I., Agil, F. Owais, M., Modern phytomedicine: Turning medicinal plants into mixtures, Johon Wiley \& sons. West-Sussex. 2006.

[2] Aparajeya, P. Sanghamitra, N. Somanatha, J. Pramod, K.S., Payodhar, P. Hin Publ Corp,. 2015;6:1-5.

[3] Baumann, E. Stoya, G. Volkner, A. Richter, W. Lemke, C. et al. Hemolysis of human erytrocytes with saponin affects the membrane structure. Acta histochemia. 2005.

[4] Brezis, M. Heyman, S.N., Dinour, D., Epstein, F.H., Rosen, S. Role of nitric oxide in renal medullary oxygenation. Studies in isolated and intact rat kidney. J Clin Inv 1991; 88(2): 390-5.

[5] Dwicahmi, P. Uji Aktivitas antibakteri ekstrak etanol $70 \%$ daun karamunting (Rhodomyrtus tomentosa (Ait.) Hassk) terhadap pertumbuhan bakteri Vibrio cholerae secara in vitro. Jurnal Mahasiswa PSPD FK Universitas Tanjungpura, 2015:3 (1).

[6] Fauci, A.S., Braunwald, E,. Kasper, D.L., Hauser, S.L., Longo, D,L., et al. Harrison's principles of internal medicine. 17th ed. United States: McGraw-Hill Professional, 2008.

[7] Gauthier, C. Legault, J. Girard-Lalancette, K. et al. Haemolytic activity, cytotoxicity and membrane cell permeabilization of semi-synthetic and natural lupane- and oleanane-type saponins. Bioorg Med Chem. 2009; 17:2002-8.

[8] Gutierrez, E. Egido, J. Rubio-Navarro, A. Buendia, I. Colio, L.M.B., et al. Oxidative stress, macrophage infiltration and CD163 expression are determinats of long term renal outcome in macrohematuria-induced acute kidney injury of $\operatorname{IgA}$ nephropathy. Nephron Clin Pract. 2012; 121:c42-c53.

[9] Hasibuan, R. Ilyas, S. Hanum, S. Effect of leaf extract Haramonting (Rhodomyrtus tomentosa) to lower blood sugar levels in mice induced by alloxan. International Journal of PharmTech Research 2015;8(6): 284-291.

[10] Jannete, J.C., Olson, J.L., Silva, F.G., D’Agati, V., editor. Heptinstall's Pathology of the Kidney. 7 ed. New York. Philadelphia: Wolters Kluwer; 2015.

[11] Kissinger, Zuhud, E.A.M., Darusman, L.K., Siregar, I.Z., Keanekaragaman jenis tumbuhan obat dari hutan kerangas. Jurnal hutan tropis. 2013, 1(1):4.

[12] Kumar, V. Abbas, A.K., Aster, J.C., Buku Ajar Patologi Robbins. Trans Krisnuhoni, E. Singapore: Elsevier; 2015.

[13] Lukacinova, A. Mojzis, J. Benacka, R. Keller, J. Maguth, T. Kurila, P. Vasko, L. Racz, O. Nistiar, F. Preventive effects of Flavonoids on Alloxan-induced Diabetes Mellitus in rats. Acta Vet. Brno, 2008, 77, 175-182.

[14] Moneim, A.A., Ahmed, O,M., Fahim, H.I., Mohamed, E.E., The Preventive Effects of Avocado Fruit and Seed Extracts on Cardio-nephrotoxicity Induced by Diethylnitrosamine/2- acetylaminoflurine in Wistar Rats. J. Medicine. 2017;6(1):413. 
[15] O'Callaghan, C., Brenner, B.M., The kidney at a glance. Oxford: Blackwell Science Ltd, 2000 .

[16] Rastogi, V. Puri. N. Arora, S. Kaur, G. Yadav, L. Sharma, R. Artefacts: A Diagnostic Dilemma - A review. J Clin Diagnostic Res. 2013;7(10):2408-13.

[17] Rinku, Y.P., Shubhangi, A.P., Niranjan, D.C., Yogesh, N.P,. Herbal drug nanoparticles:advancementsin herbal treatment. Research J. Pharm. and Tech,. 2018,11(1);421-426.

[18] Robbins, S.L., Kumar, V. Buku ajar patologi anatomi , edisi ke-6. Jakarta: EGC.2007,572, 595-7.

[19] Scapagnini, G. Allan, D.B., Colombrita, C. Sultana, R. Pascale, A. Calabrese, V. Ethyl Ferulate, a Lipophilic polyphenol, Induces HO-1 and Protect Rats Neurons Against Oxidative Stress, Antioxidants and redox signaling.2004, 6:811-18.

[20] Sestili, P. Guidarelli, A. Dacha, M. Cantoni, O. Quercetin prevents DNA single strand breakage and cytotoxicity caused by tertbutylhydroperoxide: Free radical scavenging versus iron chelating mechanism. Free Radical Biology and Medicine. 1998, 25: 196-200.

[21] Sharma, A.T., Mitkare, S.S., Moon, R.S., Multicomponent Pharmaceutical Science Revi ew and Research. 2011, 6:185-187.

[22] Sinata, N. Helmi, A. Antidiabetes dari Fraksi Air Daun Karamunting (Rhodomyrtus tomentosa (Ait.) Hassk.) terhadap Kadar Glukosa Darah Mencit Diabetes. J Sains Farm \& Klin, 2016,3(1);72-78.

[23] Song, Y. Manson, J. Buring, J.E., Sesso, H.D., Liu, L. Association of dietary flavonoids with risk of type 2 diabetes markers of insulin resistance and systemic inflammation in women: A prospective study and cross-sectional analysis. J Amer College of Nut, 2005: 24(5), 376-384.

[24] Tommy. Uji efek renoprotektif fraksi n-heksan daun kesum (polygonum minus huds.) Sebagai ko-kemoterapi pada tikus putih jantan galur wistar pasca induksi cisdiamminedichloridoplatinum(II). Jurnal Mahasiswa Farmasi Fakultas Kedokteran dan Ilmu Kesehatan UNTAN. 2013, 1(1).

[25] World Heatlh Organization (WHO). Medicinal plants in vietnam. Hanoi: Institute of Materia Medica,1989. 